\title{
Diversification of lentil production
}

\author{
M.G. Zagoruyko, M.Ye. Chaplygin, and S.A. Davydova* \\ Federal State Budgetary Scientific Institution 'Federal Scientific Agroengineering Center VIM’, 5, $1^{\text {st }}$ \\ Institutsky Drive, Moscow, 109428, Russia
}

\begin{abstract}
Production and processing of lentil as a valuable leguminous crop with a high content of beneficial nutrients (fiber, protein, minerals and vitamins), a low glycemic index, and a low-calorie content (295 kcal per 100 grams of raw lentils) has great potential for domestic economy. The world market of lentil is analyzed, prospects for increasing the level of its use in domestic markets are identified. An evaluation of the crop processing by an extrusion method is given. The statistical data of the Federal State Statistics Service, the Ministry of Agriculture of Russia, information materials of Russian and foreign research organizations and companies are studied. The methods of complex structural-dynamic analysis and the expert-analytical method of data processing are used. It is found that lentils contain the largest amount of protein among the rest of the plants, which is a source of essential amino acids (isoleucine and lysine), and that the use of this crop in feed production along with soya bin is promising and appropriate. Based on the analysis of gross yields of lentil in federal districts of Russia in 2010-2019 and export supplies of the crop revealed that the domestic lentil export market expanded 6.1 times, but the country's lentil consumption decreased 1.18 times. Thus, in the current economic conditions, the issue of finding the use of lentils as a raw export product and expanding the potential for using lentils in the domestic market is relevant. It is proposed to expand the possibilities of using lentils by extruding it, which will allow to have high quality products with good biological value and consumer properties on the domestic market.
\end{abstract}

\section{Introduction}

Lentil (Lens culinaris Medik) is the most important leguminous crop (niche crop), which is of great economic importance - is widely cultivated as a food and feed plant. As a wild plant, lentils are nowhere to be found. Lentils have been known in Russia since the 14th century; and at the beginning of the 20th century, Russia became a monopolist in the market of lentil supply to Europe and its cultivated area occupied about $70 \%$ of the world. However, due to the poor technical equipment of the farms and the underdeveloped seed production of lentils, the cultivated area under it was reduced.

Lentil is a valuable product with a high content of amino acids (glutamic and aspartic acids, significant mass fractions of tyrosine - 18.4-28.3 mg\%, threonine - 16.9-20.5 mg\%, methionine - 15.4$26.9 \mathrm{mg} \%$ ), of which more than one third (by quantity) of the sum of all amino acids is present. The

* Corresponding author: davidova-sa@mail.ru 
average protein content in lentils is higher than in other legumes (Table 1), and the maximum content is up to $35 \%$ - this is more than in soya bin and meat. Lysine content in lentil proteins is like that of animals, and this indicator is 2-2.5 times higher than in cereal crops [1-3]. Lentil seeds are rich in various macro-, microelements and vitamins: magnesium -80-300 mg/100 g; iron - 6.9-7; zinc - 2-5; selenium - 60; potassium - 1500; calcium - 83; phosphorus - 390; boron and manganese - 1.3; copper, molybdenum, as well as vitamins B1 - 0.1-0.5; B3 - 1.8; B5 - 1.4; Biotin B6 - 0.6-0.85; folic acid - 104 $\mathrm{mg} / 100 \mathrm{~g}$; vitamin C [4]. Besides, the cold-resistant and moisture-hungry plant is an excellent precursor for many crops, as it enriches the soil with nitrogen. Regardless of the farming conditions, lentils do not accumulate nitrates, nitrites, radionuclides and other substances toxic to human health [1-3].

Table 1. Main components of the chemical composition of grain legume crops

\begin{tabular}{|l|c|c|c|c|c|}
\hline \multirow{2}{*}{ Crop } & \multicolumn{5}{|c|}{ Average mass fraction,\% to dry matter } \\
\cline { 2 - 6 } & Crude protein & Fat & Ash & Starch & Fibre \\
\hline Kidney beans & 24.3 & 1.8 & 4.9 & 47.3 & 3.8 \\
\hline Peas & 27.8 & 1.2 & 3.3 & 43.2 & 4.5 \\
\hline Soya beans & 39.0 & 20.5 & 5.8 & 3.0 & 4.8 \\
\hline Lentils & 30.4 & 1.1 & 3.3 & 43.4 & 3.6 \\
\hline
\end{tabular}

Thus, the ratio and amount of macronutrients in lentil allows it to be used to produce multicomponent, functional foods, both in Russia and abroad. In terms of protein content, the crop is inferior to soya bean, but surpasses the widely used peas and kidney beans. Application of this crop in the food industry and feed production is undoubtedly promising and appropriate.

\section{Purpose of the study}

Analyze the global lentil market, identify prospects for increasing its use in domestic markets. Assess the processing of the crop by extrusion.

\section{Materials and methods}

We studied materials published in the periodical press, statistical data of the Federal State Statistics Service and the Ministry of Agriculture of Russia, information materials of Russian and foreign research organizations and companies, laws and regulations. We used methods of complex structural-dynamic analysis and an expert-analytical method of data processing.

\section{Results and discussions}

In the Russian Federation, since 2010 the area under grain legume crops has been increasing mainly due to the expansion of soya bean cultivation, the annual growth of cultivated areas under soya bean is on average more than 200 thousand ha. According to the Federal State Statistics Service, in 2019, grain legume crops (including soya beans) occupied only $6.6 \%$ of the cultivated area structure, which is extremely insufficient for a rational development of agriculture. In 2017, lentil crops increased by 2.6 times compared to 2016 and amounted to 167.4 thousand ha; in 2018 - 271.4 thousand ha; in 2019 - 274 thousand ha [5-7].

Currently, the leader in gross yield of lentils is the Volga Federal District. Over the past decade, the Siberian Federal District has shown activity in the cultivation of this crop and 
rightfully took second place, there is also some interest in lentil production in the Southern Federal District (Table 2, Fig. 1) [7].

Table 2. Lentil production rating of regions in 2017-2018.

\begin{tabular}{|l|c|c|c|c|c|c|}
\hline \multirow{2}{*}{ Russian region } & \multicolumn{2}{|c|}{$\begin{array}{c}\text { Cultivated area, } \\
\text { thousand ha }\end{array}$} & \multicolumn{2}{c|}{$\begin{array}{c}\text { Gross yield, thousand } \\
\text { tons }\end{array}$} & \multicolumn{2}{c|}{ Productivity, tha } \\
\cline { 2 - 7 } & 2017 & 2018 & 2017 & 2018 & 2017 & 2018 \\
\hline $\begin{array}{l}\text { Saratov Region } \\
\text { (Volga Federal District) }\end{array}$ & 36.8 & 81.1 & 65.3 & 45.7 & 17.9 & 6.1 \\
\hline $\begin{array}{l}\text { Altai Region } \\
\text { (Siberian Federal District) }\end{array}$ & 66.6 & 80.3 & 64.6 & 73.2 & 10.1 & 9.6 \\
\hline $\begin{array}{l}\text { Omsk Region } \\
\text { (Siberian Federal District) }\end{array}$ & 29.1 & 26.1 & 23.9 & 23.1 & 8.2 & 9.5 \\
\hline $\begin{array}{l}\text { Penza Region } \\
\text { (Volga Federal District) }\end{array}$ & 9.1 & 16.1 & 12.0 & 11.0 & 13.5 & 7.8 \\
\hline $\begin{array}{l}\text { Volgograd Region } \\
\text { (Southern Federal District) }\end{array}$ & 2.0 & 11.6 & 3.0 & 7.2 & 15.2 & 6.5 \\
\hline $\begin{array}{l}\text { Samara Region } \\
\text { (Volga Federal District) }\end{array}$ & 5.7 & 9.2 & 7.03 & 7.01 & 12.4 & 8.7 \\
\hline $\begin{array}{l}\text { Stavropol Region } \\
\text { (North Caucasian Federal District) }\end{array}$ & 1.9 & 8.1 & 2.3 & 3.1 & 12.8 & 4.8 \\
\hline $\begin{array}{l}\text { Republic of Crimea } \\
\text { (Southern Federal District) }\end{array}$ & 3.4 & 7.9 & 4.1 & 2.2 & 12.4 & 4.0 \\
\hline $\begin{array}{l}\text { Orenburg Region } \\
\text { (Volga Federal District) }\end{array}$ & 3.5 & 7.5 & 4.3 & 5.3 & 12.7 & 7.6 \\
\hline $\begin{array}{l}\text { Rostov Region } \\
\text { (Southern Federal District) }\end{array}$ & 1.4 & 5.4 & 2.5 & 3.6 & 18.8 & 7.2 \\
\hline \begin{tabular}{l} 
Russian Federation \\
\hline
\end{tabular} & 167.4 & 271.4 & 197.9 & 194.7 & 12.1 & 7.9 \\
\hline
\end{tabular}

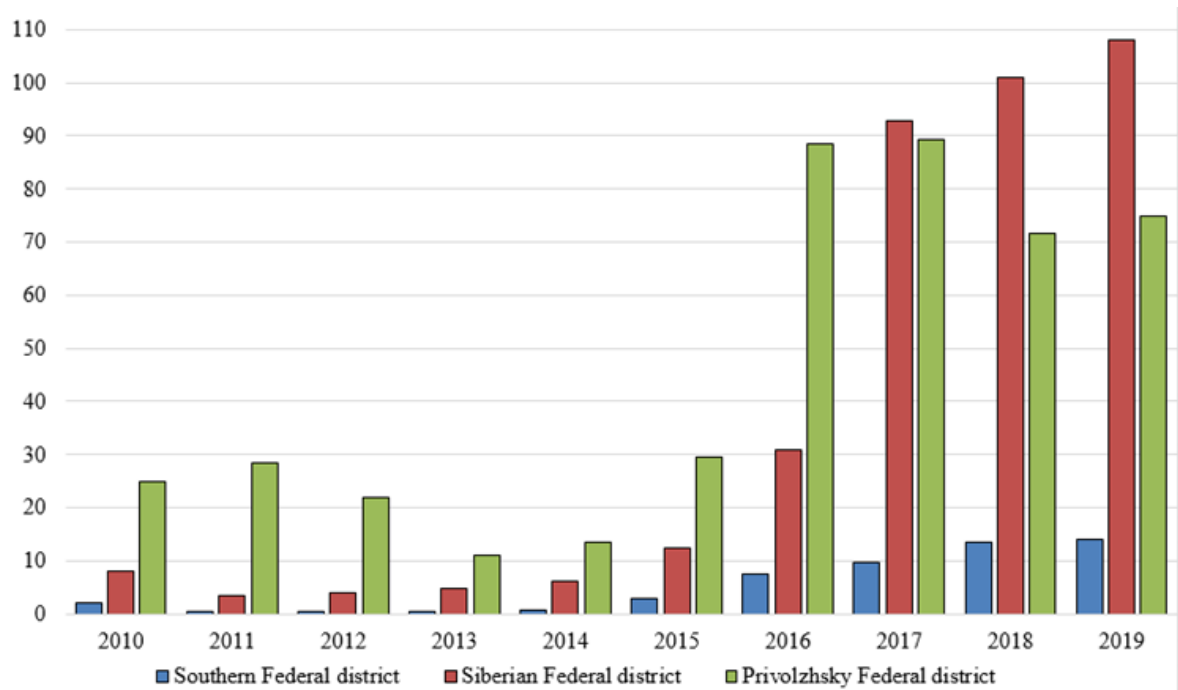

Fig. 1. Dynamics of lentil gross yields in federal districts of Russia in 2010-2019, thousand tons 
Thus, the expansion of areas under lentils did not lead to a decrease in productivity, although the indicator in the Russian Federation is quite low - $7.9 \mathrm{~kg} / \mathrm{ha}$ (kidney beans - 15.6 $\mathrm{kg} / \mathrm{ha}$; peas - 16.6; soya beans - $14.7 \mathrm{~kg} / \mathrm{ha}$ ). Lentil production is growing at a noticeable rate, which is due to the significant orientation of cultivation for export [8]. According to the specialists of the AB center, in 2015, lentil export deliveries amounted to 7.4 thousand tons; in 2016 - 17.2; in 2017 - 64.6 thousand tons. According to the results of 2018-2019 further growth in exports is expected, as sales will take into account the carryover, produced and unrealized volumes of previous years. In general, over a ten-year period, the volume of the Russian lentil market expanded 6.1 times [9].

In total, Russia supplies lentils to more than 20 countries. The leading directions in the sale of lentils are Turkey, Armenia, Bulgaria, where more than $60 \%$ of the total volume is exported (Fig. 2) [9]. From 2015, the volume of export deliveries of lentils abroad increased to more than 20 times and, according to the results of three quarters of 2019, amounted to 95 thousand tons, and the main importing countries of Russian lentils became the Arab Emirates, Iran and Turkey (18.5 million \$) [9].

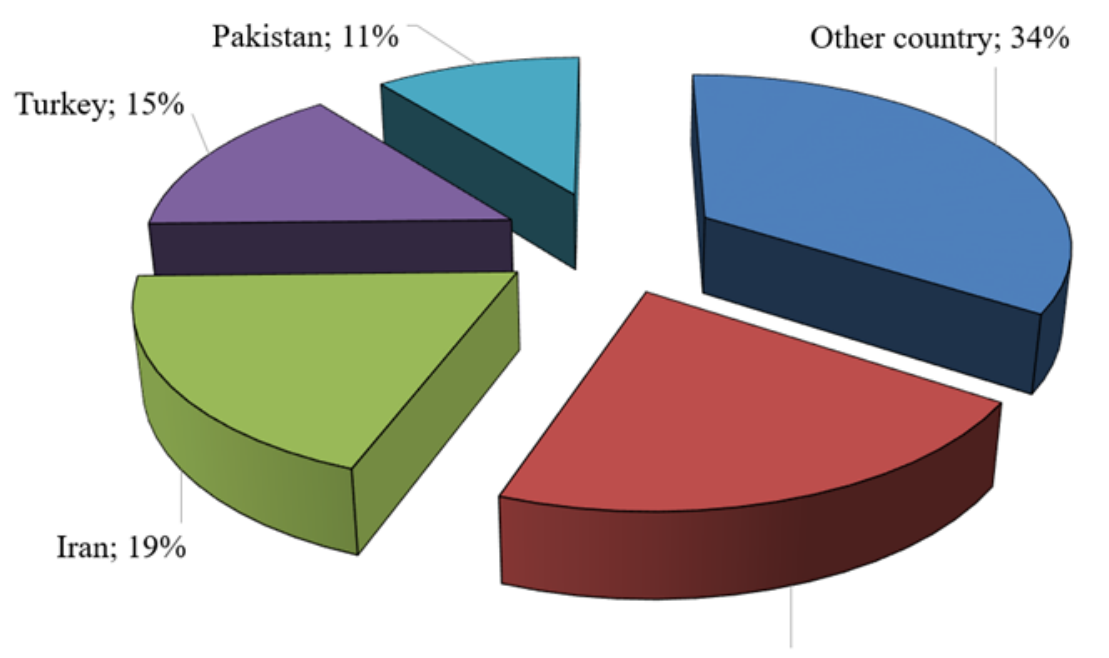

United Arab Emirates; 21\%

Fig. 2. Lentil export from Russia by country of destination.

The outgoing vector of increasing export volume can change its direction; this can be affected by fluctuations in the environment, climatic factors in individual regions, as well as an increase in world production.

In recent years, Canada has been the leader in the global lentil market. However, against the background of lower prices and as the supply of legumes to the world market increases, there is a decrease in export prospects for Canadian farmers (Fig. 3). For example, India introduced a 40 percent duty on the import of chickpeas and lentils, since the country recorded a high yield of these crops and the need arose to use its own surplus stock [9].

Another constraining factor for export deliveries from Russia was the unfavorable price situation for lentils: according to the results of the reporting period of 2019, prices fell by more than half (\$ 340 per ton) [9]. 


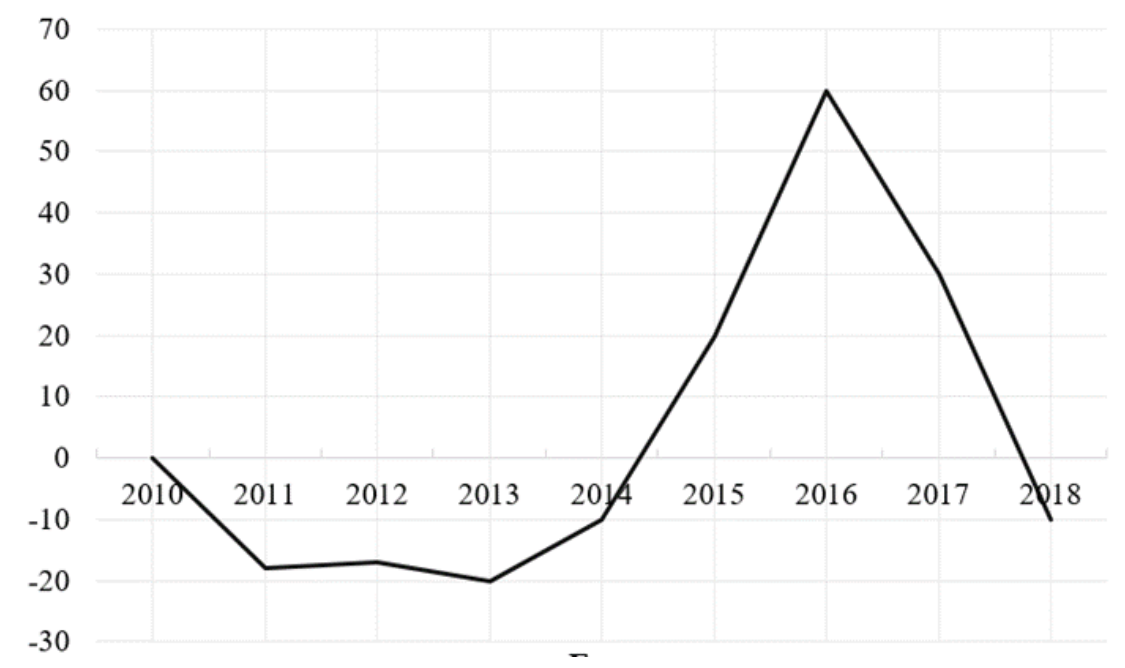

Fig. 3. Changes in lentil cultivated areas in Canada.

Besides, there is a negative trend in the domestic lentil market: the average annual volume of the domestic market over the past five-year period, according to the AB Center estimates, amounted to 46.8 thousand tons; according to the results of 2019, the consumption of lentils in Russia decreased by $15 \%$ compared to previous years [9]. Thus, in the current economic conditions, not only the issue of search for the use of lentils as a raw export product is relevant, but also the expansion of the potential for using lentils is of high practical importance.

Currently, lentils are used in Russia in the following areas [10]:

- development of recipes and technologies for combined foods close or similar in taste to dairy and fermented milk products;

- obtaining foods with high biological value as a result of mixing and sharing of proteins of plant and animal origin;

- replacing raw meat with lentil flour (reducing the proportion of fat by $1.2-4.4 \%$ and increasing the proportion of protein by 1.6-3.1\%);

- texturing of protein isolates of lentils and development of meat artificial products on their basis;

- use of green mass, chaff and straw of lentils as animal feed (the green mass of lentils is not inferior to peas in protein content; hay is close to clover in terms of feed quality and is readily eaten by all types of farm animals);

- use of the agricultural value of lentils as a precursor (in symbiosis with nodule bacteria, lentil plants capture atmospheric nitrogen, which is used in the production process, with some of the symbiotic nitrogen (40-90 kg/ha) remaining in the soil).

Given its important role in providing the population with valuable vegetable protein and high export potential, domestic crop breeders in the last decade have paid great attention to the creation of varieties with a complex of positive characteristics and properties, of which the most important are high productivity, drought tolerance, manufacturability and product quality [11].

An increase in the use of lentils also involves improvement of processing technologies for plant stock. The analysis of existing lentil processing technologies showed the lack of scientifically based domestic technology. In world practice, the technology of processing lentils into cereals is common. As a rule, lentil grain contains a large amount of difficult to separate impurities. Therefore, in preparing grain for processing, much attention is paid to its 
cleaning. A lentil grain is relatively small and brittle, therefore, a correct selection of equipment, schemes and cleaning modes, the use of optical sorters, special processing methods, etc. are important.

One of the promising methods of lentil processing is extrusion, similar to soya bean processing. At the same time, lentils are very close to soya beans in nutritional composition (Table 1), and in many respects exceed the indicators of the latter. The advantage of extruding lentils in comparison to soya beans is the fact that the fat content in lentils is very low (lentils - $1.1 \%$ to dry matter; soya beans $-20.5 \%$ to dry matter), which will eliminate the degreasing process in the technology of meat product manufacturing, and will allow to use vegetable raw materials based on lentils when feeding farm animals [13]. During extrusion, the grain is subjected to a powerful complex force and heat effect, accompanied by shear deformations in the volume of the processed plant material. The resulting product has a high degree of digestibility.

The experience of extrusion treatment of lentils shows that the total content of proteins and essential amino acids does not change, the percentage of individual fractions is redistributed (the water-soluble fraction decreases from 58.0 to $26.4 \%$; the salt-soluble fraction increases (from 4.4 to 11.0\%); alkali-soluble fraction increases (from 9.3 to 29\%) and alcohol-soluble fraction increases (from 2.6 to $3.7 \%$ ); the total biological value is $41.5 \%$. After the extrusion treatment, the total amount of starch decreases (from 52.69 to $36.39 \%$ ), with an increase in the amylose content (from 39 to 57.25\%), the total amount of oligosaccharides decreases mainly due to stachyose and verbascose; the negative effect of trypsin inhibitor is completely neutralized. During extrusion, an increase in the water holding capacity of lentils and a decrease in the rate of its swelling are observed [12].

However, a feature of extruder presses is complexity and variety of treatment processes of plant materials, therefore, the purpose of further research to improve the technology of lentil extrusion is to identify the basic laws of the process, to establish the mechanism, nature and duration of the process, to study physico-mechanical factors (shear rate, temperature, voltage, and pressure).

\section{Conclusions}

It was revealed that lentil production is growing at a noticeable rate, which is due to the significant orientation of the cultivation of this crop for export: over the ten-year period, the Russian lentil market expanded 6.1 times. However, negative trends in the global and the underdeveloped domestic Russian lentil market (the average annual domestic market volume over the past five-year period is 46.8 thousand tons; a 15\% reduction in lentil consumption in Russia) make lentil use relevant as a raw export product and make it relevant to expand the potential use of lentils.

We have identified the need to diversify lentil production: use crops not only as a raw export product, but also expand the possibilities of its use, namely extrusion, which will allow us to have high-quality products with good biological value and consumer properties on the domestic market. Further research goals have been set to improve lentil extrusion technology. It is necessary to develop and reduce the energy intensity of technical means: extruders, expanders, machines and complexes for deep processing of lentils, considering its biochemical properties.

\section{References}

1. Kalashnikova S.V., Tertychnaya T.N. Modern Aspects of Lentil Production // Technologies and Commodity Science of Agricultural Products. 2019. No. 2 (13). P. 
116-119.

2. Gridneva Ye.Ye., Kaliakparova G.Sh. Lentils as Valuable Leguminous Crop for Kazakhstan // Problems of Agricultural Market. 2019. No. 2. P. 160-166.

3. Belyaeva I.A., Koverchenko A.A., Kholodova Ye.N. Use of Lentils to Increase Biological Value of Food Products // Modern Science and Innovations. 2016. No. 3. P. 94-101.

4. $\quad$ Putyatin Yu.V., Seraya T.M., Markevich D.V., Tavrykina O.M. Comparative Analysis of Composition of Essential Amino Acids in Major Crop Production // Institute of Soil Science and Agrochemistry of the NAS of Belarus. 2014. No. 3. P. 60-68.

5. National Report on Progress and Results of Implementation in 2018 of State Program for the Development of Agriculture and Regulation of Agricultural Products, Raw Materials and Food Markets for 2013 - 2020. M., 2019. 248 p.

6. Zotikov V.I., Sidorenko V.S., Gryadunova N.V. Development of Leguminous Crop Production in the Russian Federation // Effective Plant Growing. 2018. No. 6. P. 46-49.

7. Cultivated Areas of the Russian Federation in 2019 (spring accounting): Catalog. - M.: Rosstat, 2019.

8. Dorokhov A.S., Starostin I.A., Chilingaryan N.O., Sysoev G.V. Export-Oriented Crops, State of Production and Technical Support // International Scientific Journal. 2019. No. 5. P. 51-59.

9. Plugov A.G. Global Lentil Market Review: Analytical Review. M.: AB-Center., 2019. -22 p.

10. Kondykov I.V. Lentil Culture in the World and the Russian Federation (Review) // Legumes and Cereals. 2012. No. 2. P. 13-20.

11. Yatchuk P.V. Current State of Lentil Production // Legumes and Cereals. 2018. No. 4 (28). P. 110-112.

12. Bykh G.M., Mansurov A.P., Bocharov V.A. Investigation of Extrusion Effect on Technological and Colloidal Properties of Lentil Flour // Bulletin of Michurinsk State Agrarian University. 2016. No. 1. P. 80-84.

13. Nikitin Ye.A., Dorokhov A.S., Pavkin D.Yu. Improving the Technology of Feed Mixture Preparation during Reconstruction of Feed Sites // Village Machinery and Equipment. 2019. - No. 11 (269). P. 32-35. 